ks. Janusz Mieczkowski, Jarosław A. Superson SAC

\title{
VI Międzynarodowe Sympozjum Liturgiczne (Monastero di Bose, 5-7 czerwca 2008)
}

W dniach 5-7 czerwca 2008 roku w klasztorze w Bose odbyło się VI Międzynarodowe Sympozjum Liturgiczne pt. Assemblea Santa. Forme, presenze, presidenza (Zgromadzenie święte. Formy, obecności, przewodniczenie). Spotkanie to zorganizowała Wspólnota Bose wraz z Narodowym Urzędem dla Kościelnych Dóbr Kultury przy Konferencji Episkopatu Włoch. Komitet naukowy tworzyli: Enzo Bianchi, Stefano Russo, Goffredo Boselli, Frédédic Debuyst, Paul De Clerck, Albert Gerhards, Angelo Lamieri, Keith Pecklers, Giancarlo Santi. W sympozjum uczestniczyło około 220 osób z 18 krajów.

Przywitał ich opat Wspólnoty z Bose Enzo Bianchi, który umieścił tematykę obecnych obrad na tle dotychczasowych międzynarodowych spotkań w tym miejscu. Ołtarz i ambona „powołują” zgromadzenie, natomiast zgromadzenie kreuje przestrzeń liturgiczną, w której to zgromadzenie się wyraża jako zgromadzenie celebrujące. „Zgromadzenie nie zwołuje się samo ale ołtarz i ambona wyprzedzają zgromadzenie”.

Natomiast Stefano Russo, dyrektor Narodowego Urzędu dla Kościelnych Dóbr Kultury przy Konferencji Episkopatu Włoch, podkreślił, że chrześcijańskie zgromadzenie jest podmiotem celebrującym liturgię. Jest ono święte mocą Tego, który jest święty.

Abp Piero Marini zauważył przewrót, jaki dokonał się w XX wieku. Do Soboru Watykańskiego II nie dostrzegano w magisterium Kościoła znaczenia zgromadzenia, natomiast posoborowy wstęp do mszału rzymskiego podkreśla funkcję zgromadzenia, które celebruje liturgię.

Pierwszym referentem był benedyktyn Frédéric Debuyst, który w referacie: L'assemblea vivente: una pienezza sempre incompiuta (Zgromadzenie żyjące: petnia zawsze niedokończona) posłużył się obrazem morza by wyrazić, że Kościół jak morskie fale ma w sobie życie. Ciągle działa, a jednak nigdy nie jest w stanie do końca wyrazić swojego posłania; nie jest w stanie tu na ziemi się spełnić. Już w pierwszym znanym nam budynku kościelnym (Dura Europos) autor zidentyfikował miejsca zajmowane przez zgro- 
madzenie: miejsce na eucharystię, chrzest, działalność charytatywną i pozaliturgiczną. Ważnym locus było główne wejście do domu, gdzie „rozpoczynało", konstytuowało się zgromadzenie.

Drugie wystąpienie pt. Corpi chiamati a formare un Corpo (Ciała wezwane do formowania Ciała) należało do Giuseppe Busani, dyrektora Stowarzyszenia Profesorów Liturgiki we Włoszech. Według niego, choć zgromadzenie składa się z wielu ciał, wyraża ono jedną rzeczywistość niewidzialną - wiarę. Stało się to możliwe na skutek wcielenia Chrystusa. To, co widzialne, może zawierać rzeczywistość niewidzialną. Ciało wezwane jest do sformułowania niewidzialnego Ciała w głębokim sensie communio z Bogiem. Może to czynić, używając wszystkich zmysłów. Ludzkie zmysły (ciało) i spełniany ryt dają człowiekowi możliwość wyrażania się i spotkania z Bogiem.

Kolejnym mówcą był Giuliano Zanchi, który podjął temat: Tipologia e topografia: l'assemblea liturgica nella storia (Typologia i topografia: zgromadzenie liturgiczne w historii). Przedstawił on rozwój idei obecności Boga wśród zgromadzenia. W Starym Testamencie Jahwe był jakby „podróżnikiem”, który pod postacią ognia czy obłoku kroczy wraz ze swoim ludem. Jezus Chrystus natomiast jest Bogiem żywym przez fakt wcielenia. Można było Go zobaczyć, dotknąć, posłuchać. Mimo to pozostawił uczniom obietnicę, że gdzie dwaj albo trzej będą zgromadzeni w Jego imię, tam On będzie pośród nich. Forma Kościoła wyraża, kim są wierzący w Chrystusa. Na tę formę mają wpływ: dzień, w którym zgromadzenie wiernych się odbywa, przewodniczący zgromadzenia, obecni, a nawet ci, którzy w nim bezpośrednio nie uczestniczą, ale którym zanoszona jest Eucharystia. Prelegent zauważył, że w średniowieczu nastąpiła jednak fragmentaryzacja zgromadzenia liturgicznego w Kościele zachodnim: na uczestniczących w prezbiterium, obecnych w chórze i stojących w nawie kościoła. Wyraźna zmiana nastąpiła dopiero po Soborze Watykańskim II. Wyraziła się ona w zmianach w przestrzeni sakralnej, co pociągnęło za sobą zmiany w liturgii (np. podmiocie celebrującym), dogmatyce i eklezjologii.

Ostatnim referentem pierwszego dnia sympozjum był Sebastià Janeras z Katalońskiego Wydziału Teologicznego w Barcelonie, który przestawił temat: Liturgia e architettura nelle antiche chiese siriache (Liturgia i architektura w starożytnych kościołach syryjskich). Podkreślił on, że zadaniem liturgii syryjskiej było ukazanie łączności liturgii ziemskiej z niebiańską. Podział i wystrój kościoła miał symbolicznie tę rzeczywistość wyrazić. Obrazem Chrystusa był biskup, a prezbiterzy reprezentowali apostołów. Zgromadzenie było podzielone na dwie części: mężczyzn i kobiety, których oddzielała bema - symbol Jerozolimy, centrum świata. Do ołtarza, który był symbolem Golgoty, dostęp mieli tylko biskup i prezbiterzy. 
Pierwszy dzień zakończyła debata, w której najważniejszymi pytaniami były: Czy współczesne zgromadzenie liturgiczne jest doświadczane przez różnego rodzaju problemy pochodzące z zewnątrz? Czego może nauczyć nas średniowieczne zgromadzenie liturgiczne? Czy współczesna architektura koresponduje z liturgią? Czy liturgia jest formacją duchową dla kapłanów?

W drugim dniu sympozjum pierwszym relatorem był Gordon Lathrop, luteranin z Filadelfii, który przedstawił temat: Immagini di assemblea, immagini di Chiesa (Obrazy zgromadzenia, obrazy Kościoła). Punktem wyjścia były obrazy malowane na ścianach w starożytności, np. Dobry Pasterz, niewiasty udające się do grobu. Te biblijne obrazy ze ścian doprowadziły do wytworzenia się metafor zgromadzenia i Kościoła. Trzecim etapem tego rozwoju była świadomość Kościoła, który uważa, że wszystkie teksty czytane podczas liturgii oddają pewien obraz. Użycie Biblii w liturgii sprawia, że słowo ma swe źródło w Słowie. Słowo czytane i celebrowany sakrament tworzą obraz Kościoła. Rolą Słowa jest nieustanne wzywanie, aby zgromadzenie, które je słyszy, stawało się zgromadzeniem świętym. Metaforą Kościoła w historii były: miasto, oblubienica, ciało, rodzina, winnica, drzewo oliwne, naród święty.

W kolejnej części sympozjum głos zabrali architekci: Claire Génin (Paryż), Monika Schmelzer (Berlin), Georgio Della Longa (Rzym), Antonio Marchesi (Trydent), którzy przedstawiali realizację współczesnych kościołów we Francji, Belgii, Austrii, Niemczech i Italii, podkreślając w nich rolę: katedry biskupa, miejsca przewodniczenia i tabernakulum (Cattedra, sede presbiterale e riserva eucaristica: realizzazioni contemporanee in Europa).

Sesję popołudniowa rozpoczął wykład Louisa-Marie Chauveta z Instytutu Katolickiego w Paryżu, który zaprezentował temat: Il ministero della presidenza liturgica (Ministerium liturgicznego przewodniczenia). Już we wstępie podkreślił trudną rolę przewodniczącego, który z jednej strony stoi na czele zgromadzenia kroczącego od tajemnicy ku ministerium, a z drugiej sam przewodnicząc, jest sługą. Tylko w ten sposób zgromadzenie jest figurą sakramentalną. Drugą trudnością jest fakt obecności realnej Chrystusa w zgromadzeniu: „rzeczywiście potrzeba ogromnej wiary, aby Go rozpoznać", gdyż Jego obecność to nie tylko postacie eucharystyczne, ale także słowo, zgromadzenie i przewodniczący.

Następnie Albert Gerhards z Uniwersytetu z Bonn przybliżył temat: Cattedra e sede presbiterale: implicazioni teologiche della collocazione ( $\mathrm{Ka}$ tedra i miejsce przewodniczenia: implikacje ich teologicznego usytuowania). Rozpoczął on od stwierdzenia, że w starożytności przywilej siedzenia podczas liturgii posiadał tylko ten, kto jej przewodniczył. Miejsce przewodniczenia znajdowało się bądź koło ołtarza (Dura Europos), bądź w cen- 
trum absydy (bazyliki rzymskie). W średniowieczu nastąpiła zmiana w organizacji przestrzeni liturgicznej i miejsce w centrum absydy zajął ołtarz i tabernakulum. W ten sposób liturgia ziemska stała się intronizacją ofiary Chrystusa na ziemi. Tymczasem pierwsi chrześcijanie nie intronizowali Chrystusa, ale Go oczekiwali. Po Soborze Watykańskim II wyróżniono dwa miejsca: miejsce przewodniczącego i katedrę biskupa. Rodzaj proklamacji Słowa i rodzaj sprawowanego sakramentu implikują usytuowanie miejsca przewodniczenia. Drugi dzień sympozjum zakończył się dyskusją, która podkreślała, że współczesna sztuka sakralna przeżywa kryzys.

Trzeci dzień obrad rozpoczął się od referatu André Wenina z Uniwersytetu Katolickiego w Louvain-la-Neuve pt. Una dimora per Dio (Przybytek dla Boga). Obecność Boga pośród narodu wybranego widzi on etapowo: Jahwe przebywa w namiocie, posiada swoją świątynię, a następnie przebywa w słowie głoszonym przez proroków. Chrystus opuszcza świątynię, co więcej, przepowiada jej zniszczenie. Odtąd Jego uczniowie głoszący słowa życia, nie pochodzący z rodu kapłańskiego stają się świątynią Boga.

Historię przechowywania postaci eucharystycznych w Kościele zachodnim (Storia della riserva eucaristica in occidente) przedstawił Nathan Mitchell z Uniwersytetu Notre Dame w USA. Powodem przechowywania Eucharystii była na początku tylko komunia święta chorych i umierających. Zmiana nastąpiła dopiero w drugim tysiącleciu Kościoła po herezji Berengariusza. Eucharystię rozpoczęto przechowywać także do adoracji, procesji i komunii świętej poza mszą świętą.

Robert F. Taft z Papieskiego Instytutu Orientalnego w Rzymie przedstawił natomiast praktykę przechowywania i adorowania Eucharystii w tradycjach ortodoksyjnych (Custodia e venerazione dell'eucaristia nelle tradizioni ortodosse). Już we wstępie zauważył, że praktyka przechowywania Eucharystii istnieje przede wszystkim w liturgii bizantyjskiej i armeńskiej. Przez pierwsze jedenaście wieków Eucharystia przechowywana była tylko do udzielania jej chorym i umierającym lub mnichom, którzy mieli Ją przy sobie, idąc na pustynię.

Tabernakulum posiadało formy gołębia lub pawia. Niekiedy przechowywano Eucharystię w baptysterium. Kościół bizantyjski nie wypracował teologii przechowywania Najświętszego Sakramentu. Po XI wieku zdarzały się lokalne przejawy kultu, jednak również podkreśla się przyjmowanie Eucharystii podczas liturgii mszy świętej z darów przyniesionych do ołtarza. Wierny prawosławny chętniej będzie modlił się przed ikonami niż przed tabernakulum.

Sympozjum zakończyło się podsumowaniem, którego dokonał Paul De Clerck. Sens spotykania się w Bose na międzynarodowych spotkaniach litur- 
gicznych określił on drogą Kościoła. Spotkania te pomagają bowiem w opracowaniu teologii Kościoła, eklezjologii i zrozumienia jego praktyk liturgicznych.

Kraków KS. JANUSZ MIECZKOWSKI, JAROSEAW SUPERSON SAC 